\title{
Student Performance In Upper-Division Business Core Courses: Using Control Variables To Determine The Effect Of Class Size
}

\author{
Donna A. Driscoll, (E-mail: donna.driscoll@ csun.edu), California State University, Northridge \\ Paul J. Lazarony, (E-mail: paul.lazarony@csun.edu), California State University, Northridge \\ Janna B. Arney, (E-mail: jbarney@utb.edu), University of Texas, Brownsville \\ Earl J. Weiss, (E-mail: earl.weiss@ csun.edu), California State University, Northridge
}

\begin{abstract}
Although the effect of class size upon student performance has been the focus of numerous studies, the results have been extremely mixed, including positive effects, no effects, and negative effects. The authors of this study believe that this lack of consensus could be due, at least in part, to the shortage of control variables employed in previous studies. The purpose of this study was to determine whether the addition of four control variables (course being taught, length of class period, instructor, and student ability level) to the analysis would be helpful in isolating the effect, if any, of class size upon student performance. To more fully explore the effects of including control variables upon the results, the control variables would be added sequentially, one at a time. The analysis would thus consist of a series of five regression sets. The first set would be a single, simple regression of student performance on class size. The second and subsequent sets would each consist of a group of simple regressions that controlled for one, two, three, and then finally all four of the control variables. The data to be used would be 113,468 course grade records (for the years 1990-2002) for 10 upper-division business core courses. Student performance would be defined as course grade; class size would be defined as either large (75 or more students) or small (60 or fewer students). The results showed that an initial slightly positive effect (.06 grade points) of class size on student performance (found in the Regression Set 1 before the addition of any control variables) changed substantially to 4 positive effects, 57 no effects, and 21 negative effects (after the addition of all four control variables in Regression Set 5). The Adjusted R-Squares also increased (from a rounded value of .000 in Regression Set 1 to a high of .428 in Regression Set 5) as did the grade point differences in performance between small and large classes (from .06 grade points in Regression Set 1 to a range of from .68 to -1.24 grade points in Regression Set 5). Although more research is certainly needed in this area before definitive conclusions can be reached about the effect of class size upon student performance, it appears that the control variable approach used in this study does shed some light on the seemingly inconsistent results of previous studies. Specifically, our results show that: (1) it quite likely (57/82 or 70\%) that there will be no significant effect of class size upon student performance, (2) if there is an effect, it will most likely $(21 / 25$ or $84 \%)$ be a negative one, and (3) the effect, if any, is highly dependent upon the specific combination of course, class length, instructor, and student ability level involved.
\end{abstract}

\section{INTRODUCTION}

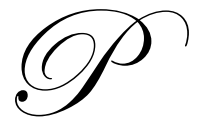

ublic colleges and universities in the United States have increasingly had to face the challenge of serving more students with fewer resources. One approach that has often been used to help meet this challenge is to increase the size of each class. Unfortunately, while the use of larger classes clearly reduces the instructional cost per student, the effects on student performance are not quite so clear. Numerous investigators have been studying such effects at all levels of education (i.e., elementary, secondary, and post-secondary) since the early part of the twentieth century, but the results have been mixed. Remarkably, positive effects, negative effects, no effects, and differential effects have all been found in the literature. 
Until the 1990s, the College of Business and Economics at California State University, Northridge, had offered only relatively small classes (i.e., no more than 60 students per class). In the last few years, however, College enrollments have followed the general trend of increasing substantially without a proportionate increase in funding. This disparity has resulted in the College's implementation of a myriad of larger class sections (i.e., from 75 to 150 students) in a lecture hall for several of its business courses, both lower and upper-division core.

Regrettably, the College has been utilizing large classes for a number of years without really knowing what impact such classes are having upon its students - and, as mentioned earlier, the inconsistent results in the literature have not provided much guidance. In light of such inconsistent research results, one must ask the question, "Why?" Why, after so many studies have been done, has no pattern of effects begun to emerge?

The investigators involved in the current study believe that the answer to this question lies in the approach used in these earlier studies; that is, earlier studies on class size used few, if any, control variables that would have allowed the researchers to really focus in on the effect that class size might have upon student performance.

The purpose of the current study was to develop and use an approach to test for class size effects in the presence of several promising control variables. More specifically, the purpose was to test for the effect of class size on student performance (using simple linear regression) and then to test for it several times again after the addition of each of the carefully selected control variables (i.e., course, class period length, instructor, and student ability level). The College's substantial experience with both large and small classes of various content and length, taught by a variety of instructors, and to large numbers of students presented a tremendous data resource for implementing this new approach. Given this purpose, the paper will proceed as follows:

- $\quad$ First, the literature on the effects of class size at the post-secondary (i.e., college and university) level will be reviewed. The results, as mentioned earlier, have been highly inconsistent, probably due to the small number of control variables (i.e., from zero to three) used in each study.

- $\quad$ Second, the methodology used here, which consisted of first using simple linear regression to test for a relationship between class size and student performance and then testing again for the same relationship after the introduction of each of four control variables (i.e., course, class period length, instructor, and student ability level) will be outlined. As mentioned earlier, this approach differs substantially from those used previously in the literature.

- $\quad$ Third, the results for each of the five regression sets will be described.

- $\quad$ Finally, a summary of the results as well as conclusions to be drawn from the study will be presented.

\section{REVIEW OF THE LITERATURE}

The relationship between class size and student performance has already been the subject of much research. Unfortunately, the findings in the literature have been far from consistent. This section of the paper presents a review of the 13 studies that were most relevant to the current inquiry (those done at the college or university level).

The review consists of four subsections:

1. Overall Findings,

2. Dependent Variable: Student Performance,

3. Independent Variable: Class Size, and

4. Control Variables: Course, Class Period Length, Instructor, and Student Ability Level.

A summary of the review is shown in Table 1. 
Table 1

Summary of Previous Studies

\begin{tabular}{|c|c|c|c|c|c|c|c|c|c|}
\hline \multicolumn{2}{|c|}{ Research Study } & \multirow{2}{*}{$\begin{array}{c}\begin{array}{c}\text { Dependent } \\
\text { Variable }\end{array} \\
\begin{array}{c}\text { Student } \\
\text { Performance }\end{array} \\
\end{array}$} & \multicolumn{2}{|c|}{\begin{tabular}{|c|}
$\begin{array}{c}\text { Independent } \\
\text { Variable }\end{array}$ \\
Class Size
\end{tabular}} & \multicolumn{4}{|c|}{ Control Variables } & \multirow{2}{*}{$\begin{array}{l}\text { Overall } \\
\text { Findings }\end{array}$} \\
\hline $\begin{array}{l}\text { Author } \\
\text { Date }\end{array}$ & $n$ & & $\begin{array}{l}\text { Clas } \\
\text { Large } \\
\end{array}$ & $\begin{array}{l}\text { Size } \\
\text { Small }\end{array}$ & Course & $\begin{array}{l}\text { Class } \\
\text { Period } \\
\text { Length }\end{array}$ & Instructor & $\begin{array}{l}\text { Student } \\
\text { Ability }\end{array}$ & \\
\hline $\begin{array}{l}\text { Eash, } \\
\text { et al. } \\
\text { (1964) }\end{array}$ & $\begin{array}{c}677 \\
\text { students }\end{array}$ & $\begin{array}{c}\text { Three } \\
\text { multiple choice } \\
\text { achievement tests }\end{array}$ & $\begin{array}{l}189 \\
208 \\
167\end{array}$ & $\begin{array}{l}31 \\
36 \\
46\end{array}$ & Psychology & * & $\begin{array}{c}\text { One for small and } \\
\text { some large classes; } \\
\text { One for remaining } \\
\text { large classes. }\end{array}$ & $\begin{array}{l}\text { Two } \\
\text { entrance } \\
\text { exams }\end{array}$ & Positive Effect ** \\
\hline $\begin{array}{l}\text { Morgan } \\
(1978)\end{array}$ & $\begin{array}{c}2,298 \\
\text { students }\end{array}$ & Course grade & $>30$ & $\leq 30$ & $\begin{array}{c}12 \text { courses; } \\
5 \text { content } \\
\text { areas }\end{array}$ & * & Full-time only & * & No Effect \\
\hline $\begin{array}{l}\text { Thibodeaux, } \\
\text { et al. } \\
(1984) \\
\end{array}$ & $\begin{array}{c}60 \\
\text { students }\end{array}$ & $\begin{array}{c}\text { Objective } \\
\text { portion of three } \\
\text { examinations } \\
\end{array}$ & 196 & 50 & Management & * & * & * & Differential Effect \\
\hline $\begin{array}{l}\text { Williams, } \\
\text { et al. } \\
(1985) \\
\end{array}$ & $\begin{array}{c}20,020 \\
\text { test } \\
\text { scores }\end{array}$ & Final exam & \multicolumn{2}{|c|}{$\begin{array}{l}\text { Continuous } \\
\text { variable }\end{array}$} & 27 courses & * & * & * & Differential Effect \\
\hline $\begin{array}{l}\text { Berghel } \\
(1986)\end{array}$ & $\begin{array}{c}2,331 \\
\text { students }\end{array}$ & Course grade & $\approx 250$ & $\approx 35$ & $\begin{array}{l}\text { Computer } \\
\text { Literacy }\end{array}$ & * & * & GPA & No Effect \\
\hline $\begin{array}{l}\text { Lindsay, } \\
\text { et al. } \\
(1987)\end{array}$ & $\begin{array}{c}1,516 \\
\text { course } \\
\text { sections }\end{array}$ & $\begin{array}{l}\text { Mean grade for } \\
\text { each section }\end{array}$ & \multicolumn{2}{|c|}{$\begin{array}{l}\text { Eight class size } \\
\text { categories }\end{array}$} & $\begin{array}{l}\text { Arts, Social } \\
\text { Studies, } \\
\text { Science } \\
\text { and "Applied" }\end{array}$ & * & * & * & Negative Effect \\
\hline $\begin{array}{l}\text { Raimondo } \\
\text { (1990) }\end{array}$ & $\begin{array}{c}146 \\
\text { students }\end{array}$ & $\begin{array}{c}\text { Course grade in an } \\
\text { intermediate course } \\
\text { taken in a } \\
\text { subsequent semester. }\end{array}$ & $\begin{array}{l}200 \\
\text { to } \\
350\end{array}$ & $\begin{array}{l}25 \\
\text { to } \\
35\end{array}$ & Economics & * & $\begin{array}{l}\text { Considered } \\
\text { instructor } \\
\text { grading policy }\end{array}$ & GPA & Differential Effect \\
\hline $\begin{array}{l}\text { Scheck, } \\
\text { et al. } \\
\text { (1994) }\end{array}$ & $\begin{array}{c}140 \\
\text { students }\end{array}$ & Course grade & $\geq 150$ & $\leq 38$ & Management & * & * & $\begin{array}{c}\text { GPA, } \\
\text { Cumulative } \\
\text { GPA }\end{array}$ & Negative Effect \\
\hline $\begin{array}{l}\text { Hou } \\
(1994)\end{array}$ & $\begin{array}{c}79 \\
\text { students }\end{array}$ & $\begin{array}{l}\text { Quizzes, } \\
\text { Mid-term, } \\
\text { final exam }\end{array}$ & 54 & 25 & Economics & * & $\begin{array}{l}\text { Used same } \\
\text { instructor }\end{array}$ & $\begin{array}{l}\text { GPA, SAT, } \\
\text { High School } \\
\text { GPA }\end{array}$ & Negative Effect \\
\hline $\begin{array}{l}\text { Gibbs, } \\
\text { et al. } \\
(1996)\end{array}$ & $\begin{array}{c}6,075 \\
\text { course } \\
\text { sections }\end{array}$ & $\begin{array}{l}\text { Mean grade for } \\
\text { each section }\end{array}$ & \multicolumn{2}{|c|}{$\begin{array}{l}\text { Continuous } \\
\text { variable }\end{array}$} & $\begin{array}{c}10 \text { content } \\
\text { areas }\end{array}$ & * & * & * & Differential Effect \\
\hline $\begin{array}{l}\text { Kennedy, } \\
\text { et al. } \\
(1997)\end{array}$ & $\begin{array}{c}2,143 \\
\text { students }\end{array}$ & $\begin{array}{c}\text { Mean scores on the } \\
\text { Test of Understanding } \\
\text { in College Economics } \\
\text { (TUCE III) }\end{array}$ & \multicolumn{2}{|c|}{$\begin{array}{l}\text { Continuous } \\
\text { variable }\end{array}$} & Economics & * & $\begin{array}{c}\text { Considered } \\
\text { delivery method } \\
\text { and instructor } \\
\text { characteristics }\end{array}$ & $\begin{array}{c}\text { GPA, } \\
\text { SAT, ACT }\end{array}$ & No Effect \\
\hline $\begin{array}{l}\text { Borden, } \\
\text { et al. } \\
\text { (1999) }\end{array}$ & $\begin{array}{l}34,246 \\
\text { students }\end{array}$ & Course grade & \multicolumn{2}{|c|}{$\begin{aligned} \text { Large } & =91+ \\
\text { Medium } & =31-90 \\
\text { Small } & =5-30\end{aligned}$} & $\begin{array}{l}\text { Introductory } \\
\text { Level courses }\end{array}$ & * & * & $\begin{array}{l}\text { Level of } \\
\text { Preparation }\end{array}$ & Differential Effect \\
\hline $\begin{array}{l}\text { Sugrue, } \\
\text { et al. } \\
\text { (1999) }\end{array}$ & $\begin{array}{c}115 \\
\text { test } \\
\text { scores }\end{array}$ & $\begin{array}{l}\text { Mid-term } \\
\text { and } \\
\text { Final exam }\end{array}$ & 63 & $\begin{array}{c}22 \\
\text { and } \\
30\end{array}$ & $\begin{array}{c}\text { Graduate } \\
\text { Managerial } \\
\text { Finance }\end{array}$ & * & $\begin{array}{l}\text { Used same } \\
\text { instructor }\end{array}$ & $\begin{array}{l}\text { GMAT and } \\
\text { Incoming } \\
\text { GPA }\end{array}$ & Negative Effect \\
\hline
\end{tabular}

Information not reported

** This configuration was not strictly comparable to the ones used in the other ten studies because the large classes were supplemented

by small discussion groups.

\section{Overall Findings}

Studies of Class Size on Student Performance have produced inconsistent results. Of the 13 examined here, three found that class size had no effect on student performance, one concluded that larger classes had a positive effect, four found a negative effect, and five found differential effects depending on the performance measure used (i.e., midterms vs. a final exam) and the course being taken. Here are some details of the findings of each study:

\section{No Effect}

- Morgan (1978)

- Berghel (1986)

- Kennedy et al. (1997)
There was no significant difference between large and small classes in 12 different courses in five content areas.

Student performance was not diminished by a large computer literacy class environment.

Larger class size did not reduce learning in principles of economics. 
2. Positive Effect

- Eash et al. (1964)

3. Negative Effect

- Lindsay et al. (1987)

- Hou (1994)

- Scheck et al. (1994)

- Sugrue et al. (1999)

4. Differential Effects

- Thibodeaux et al. (1984)

- Williams et al. (1984)

- Raimondo et al. (1990)

- Gibbs et al. (1996)

- Borden, (1999)
A large lecture class was superior to smaller lecture-discussion classes in psychology.

Percentages of $\mathrm{A}$ and $\mathrm{B}+$ grades decreased, percentages of $\mathrm{B}$ and $\mathrm{C}$ grades increased steadily as enrollments increased, and $\mathrm{F}$ grades appeared to be constant for Arts, Social Studies, Science, and Applied subjects (i.e., Catering, Cartography, Publishing, Applied Education, Accounting, Planning).

Disparity in learning was evident in favor of the smaller economics class. Large management class size had a direct negative effect on student performance.

The small distance learning site class performed better than the large distance learning site. This study also tested the difference between one non-distance learning class and two distance learning classes, one small and one large. No significant difference was found.

Mean scores on the first two of three management exams were higher for the large class; mean scores for the third exam were slightly higher for the small class.

Class size had positive, negative, or no effects on performance, depending upon which of 27 courses was being taught and upon which model (i.e., linear, logarithmic, or curvilinear) was being used:

* Linear Model - Class size was significant for four of the courses (English 115(-), Health 129(-), Religion 121(+), and Statistics $221(+))^{2}$

* Logarithmic Model - Class size was significant for six of the courses (Comm 102(+), English 115(-), Health 129(-), Religion 121(+), Social Science 100(-), and Statistics $221(+))$.

* Curvilinear Model - Class size was significant for two of the courses (English 115(+) and Health 129(+)).

A large size introductory macroeconomics course had a negative effect on performance in a subsequent intermediate macroeconomics course, but a large size introductory microeconomics course had no effect on a subsequent intermediate microeconomics course.

For the 33 courses studied, larger classes had a negative effect in 17, a positive effect in 4, and no effect in 12.

Section size was shown to have little effect on student grades and course completion rates. Section size did not have a direct effect on subsequent course taking behaviors. Class size did have a negative impact on students who enter college with academic deficiencies.

These findings are summarized in the last column of Table 1.

\footnotetext{
${ }^{1}$ This configuration was not strictly comparable to the ones used in the other ten studies because the large classes examined in this study were supplemented by small separate discussion groups.

${ }^{2}$ The numbers in parentheses represent the direction of the reported relationship.
} 


\section{Dependent Variable: Student Performance}

Student Performance has been measured in a variety of ways. All of the research reviewed for this study employed some objective and quantifiable measure, the most common ones being course grades or test scores, as shown below:

1. Course Grades

- Morgan (1978)

- Berghel (1986)

- Lindsay et al. (1987)

- Scheck et al. (1994)

- Gibbs et al. (1996)

- Borden et al. (1999)

2. Test Scores

- Eash et al. (1964)

- Thibodeaux et al. (1984)

- Williams et al. (1984)

- Hou (1994)

- Sugrue et al. (1999)

3. Other Measures

- Raimondo et al. (1990)

- Kennedy et al. (1997)

- Borden et al. (1999)
Mean grades for each class section. Grades for each individual student. Mean grades for each class section. Grades for each individual student. Mean grades for each class section. Mean grades for each class section.

The student performance measures used in the various studies have been entered into the "Dependent Variable" column of Table 1.

\section{Independent Variable: Class Size}

Class Size has been defined in three basic ways: as a binary variable indicating large vs. small classes, as a categorical variable having several size categories, or as an continuous variable indicating an actual count of the students in the class. The following list describes how class size was defined in each of the studies reviewed:

1. As a Binary Variable (i.e., Small vs. Large Classes)

- Eash et al. (1964)

- Morgan (1978)

- Thibodeaux et al. (1984)

- Berghel (1986)

- Raimondo et al. (1990)

- Hou (1994)

- Scheck et al. (1994)

- Sugrue et al. (1999)
Three multiple-choice achievement tests. Objective portion of three examinations. Final examination.

Several quizzes and one portion of each midterm and the final exam. Scores on midterm and end-of-course examinations.
Course grade in an intermediate Economics course taken in a subsequent semester.

Mean scores on the Test of Understanding in College Economics (TUCE III).

Percent of Successful Completers; those attaining a grade of C- or better.

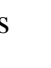


2. As a Categorical Variable (i.e., a number of class size categories)

- Lindsay et al. (1987) Eight categories: <10, 11-20, 21-30, 31-40, 41-50, 51-60, 61-70, and >70.

- Borden et al. (1999) Three categories: 5-30, 31-90, 91+.

3. As a Continuous Variable (i.e., count of the actual number of students in the class): Williams et al. (1984), Gibbs et al. (1996), and Kennedy et al. (1997)

The definitions of class size used in the various studies have been entered into the "Independent Variable" column of Table 1 .

\section{Control Variables: Course, Class Period Length, Instructor, And Student Ability Level}

The studies in the class size literature have, to varying degrees, incorporated a variety of control variables. This section presents a summary of control variables that have been employed, or merely discussed in the literature. The variables are: (1) the discipline(s) of the course(s) examined, (2) the length of the class period, (3) the individual instructor, and (4) student ability level.

1. Course(s) Examined

Eight of the studies concentrated on one course; five examined multiple content areas and courses:

a. One Course

- Eash et al. (1964)

- Thibodeaux et al. (1984)

- Berghel (1986)

- Raimondo et al. (1990)

- Hou (1994)

- Scheck et al. (1994)

- Kennedy et al. (1997)

- Sugrue et al. (1999)

Psychology

Management

Computer literacy

Economics

Economics

Management

Economics

Managerial Finance

b. Multiple Content Areas \& Courses

- Morgan (1978)

12 courses in Management, Economics, Human Services, Psychology, and Sociology.

- Williams et al. (1984)

27 courses in Accounting, Business Management, Child Development and Family Relations, Computer Science, Communications, Economics, English, Food Science and Nutrition, Health, Physical Science, Physics, Religion, Social Science, Statistics, Theater, and Cinematic Arts.

- Lindsay et al. (1987)

29 courses in Art, Social Studies, Science and "Applied."

- Gibbs et al. (1996)

33 courses in Art, Engineering, Social Sciences, Mathematics, Medicine, Education, Built Environment, Science, Business, Management, and Humanities.

- Borden et al. (1999)

Thirteen courses in Art, Biology, Chemistry, Geology, History, Mathematics, Psychology, and Sociology.

\section{Class Period Length}

Although nothing was found in the class size literature on the effect of class period length on student performance, studies in other areas of the literature have tested for this effect and have found that it can be 
significant. For example, Henebry (1997) concluded that students in a financial management class performed better in a shorter class that met more often.

\section{Instructor}

Most of the studies reviewed did not control for instructor as it impacts student performance, and only a few addressed the instructor as any kind of variable. Descriptions of the role played by the Instructor variable in the five studies that either used it or mentioned it are given below:

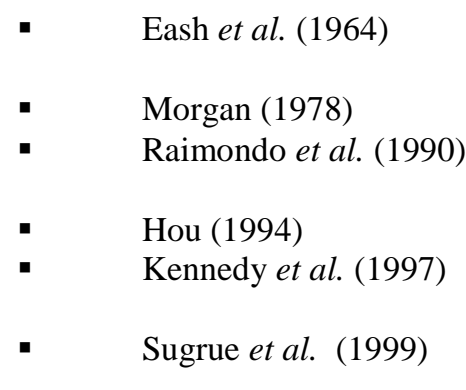
The same professor taught all of the small classes and most of the large classes; another professor taught the remaining large classes. Included courses taught by full-time faculty only.
Identified the instructors' grading policy in the subsequent course as an independent variable.
Same instructor for both courses.
Considered delivery method and instructor characteristics (i.e., tenure, experience, and instructor rating).
Same instructor for all courses.

4. Student Ability Level

GPA was used in five of the studies to measure student ability level. Entrance exams were the next most often used measure of this variable.

$\begin{array}{ll}\text { - } & \text { Eash et al. (1964) } \\ \text { - } & \text { Berghel (1986) } \\ \text { - } & \text { Raimondo et al. (1990) } \\ \text { - } & \text { Scheck } \text { et al. (1994) } \\ \text { - } & \text { Kou (1994) } \\ \text { - } & \text { Bonnedy } \text { et al. (1997) } \text { et al. }(1999)\end{array}$

- $\quad$ Sugrue et al. (1999)
Two entrance exams - the School and College Ability Test (SCAT) and the Purdue English Test (language and spelling).

Student's GPA subsequent to taking the course being measured (at the start of their junior year).

Student's GPA prior to taking the course being measured.

Student's cumulative GPA.

University and high school GPA and SAT scores.

Student's GPA and scores on SAT and ACT.

Level of preparation - the university admits students into one of three program standings depending on academic background: the least well-prepared students are entered into a "preparatory" program; those who meet entrance requirements but are not yet admitted into a specific major program (undeclared); and students who meet the entrance requirements and are admitted directly into specific schools or programs based on their background and focused interests (direct admit).

Students' GMAT (Graduate Management Achievement Test) scores and incoming GPA (grade point average).

Descriptions of the role played by each of these four control variables in the various studies have been entered into the columns under the "Control Variables" heading in Table 1.

\section{METHOD}

The methodology utilized for this study will now be described. This description is presented in three parts: (1) the data used in the study, (2) the hypothesis tested and the statistical model used, and (3) how control variables were utilized. 


\section{Data}

The data used in this study were drawn from a 333,981 record database of all the grades given in the College of Business and Economics at California State University, Northridge, during a 121/2 year period from 1990 through 2002. From this database, 113,468 records were extracted for the following 10 upper-division business core courses: (1) Managerial Accounting, (2) Business Law II, (3) Money, Income, and International Economics, (4) Economic Price Theory, (5) Financial Management, (6) Information Systems, (7) Management and Organizational Behavior, (8) Marketing Management, (9) Decision Support Models \& Methods, and (10) Operations Management. Hypothesis and Model Used

The purpose of this study is to shed some additional light on the question of whether there is a relationship between class size and student performance in upper-division business core courses. The null hypothesis to be tested is:

$\mathrm{H}_{0}$ : Class size has no effect on student performance in upper-division business core courses.

The model used to test this hypothesis is one of simple linear regression:

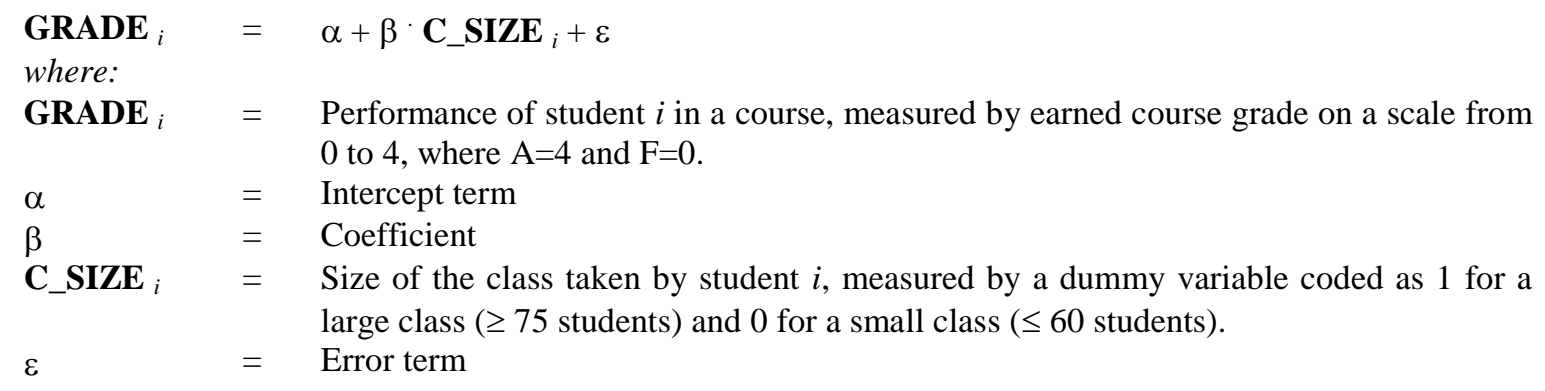

\section{Use Of Control Variables}

Five sets of simple linear regressions were performed. The first was the one just described; the other four sets were done, in turn, after adding each of the four control variables shown in Table 2.

Table 2

Control Variables Used

\begin{tabular}{|c|c|c|}
\hline Variable Name & Full Name & Description \\
\hline COURSE & Course & Each of the 10 upper-division business core courses listed previously. \\
\hline C_LENGTH & Class Period Length & Number of hours in each class meeting. \\
\hline INSTRUCTOR & Instructor & A code number indicating the faculty member who taught the class. \\
\hline S_ABILITY & Student Ability Level & $\begin{array}{l}\text { A calculation done in two steps: } \\
\text { 1. Compute student i's grade point average for lower division } \\
\text { business core courses (i.e., Principles of Accounting I, Business } \\
\text { Law I, Principles of Economics, Statistical Methods, and } \\
\text { Business Communications) taken at this University during the } \\
\text { period from 1990 to 2002. } \\
\text { 2. Assign student i's to one of four categories: "Excellent" } \\
(>=3.33) \text {, "Good" ( }>=2.67) \text {, "Average" }(>=2.00) \text {, and } \\
\text { "Probation" ( }>=1.7),{ }^{3} \text { based on the averages computed in step } \\
\text { (1). }\end{array}$ \\
\hline
\end{tabular}

3 Since students who have below a 1.7 average at the end of their sophomore year are no longer matriculated students (although they are allowed to continue taking classes on a space-available basis), they are not included in this study. 
The completed regression sets are defined graphically in Table 3,

Table 3

Planned Regression Sets

\begin{tabular}{|c|c|c|c|c|c|c|}
\hline \multirow{2}{*}{$\begin{array}{c}\text { Regression } \\
\text { Set }\end{array}$} & $\begin{array}{c}\text { Dependent } \\
\text { Variable }\end{array}$ & $\begin{array}{c}\text { Independent } \\
\text { Variable }\end{array}$ & \multicolumn{5}{|c|}{ Control Variables } \\
\cline { 2 - 7 } & GRADE & C_SIZE & COURSE & C_LENGTH & INSTRUCTOR & S_ABILITY \\
\hline 1 & $\mathrm{X}$ & $\mathrm{X}$ & & & & \\
\hline 2 & $\mathrm{X}$ & $\mathrm{X}$ & $\mathrm{X}$ & & & \\
\hline 3 & $\mathrm{X}$ & $\mathrm{X}$ & $\mathrm{X}$ & $\mathrm{X}$ & & \\
\hline 4 & $\mathrm{X}$ & $\mathrm{X}$ & $\mathrm{X}$ & $\mathrm{X}$ & & $\mathrm{X}$ \\
\hline 5 & $\mathrm{X}$ & $\mathrm{X}$ & $\mathrm{X}$ & $\mathrm{X}$ & $\mathrm{X}$ & \\
\hline
\end{tabular}

Note: $\mathrm{X}$ indicates which variables are included in each regression set, either as a dependent, independent, or control variable and presented in narrative form here:

- $\quad$ Regression Set 1 consisted of a single simple regression of GRADE on C_SIZE for all of the 10 upperdivision business core courses listed previously.

- $\quad$ Regression Set 2 narrowed Set 1 to include only those courses that had been offered in both the large and small formats. This set also controlled for COURSE by including a separate simple regression (of GRADE on C_SIZE) for each course.

- $\quad$ Regression Set 3 narrowed Set 2 further to include only those COURSE and C_LENGTH combinations which had been taught in both large and small size formats. This set controlled for the two variables by including a simple regression (of GRADE on C_SIZE) for each combination.

- $\quad$ Regression Set 4 narrowed Set 3 even further to include only COURSE and C_LENGTH and INSTRUCTOR combinations taught both in large and small sections. This set controlled for the three variables by including a simple regression (of GRADE on C_SIZE) for each combination.

- $\quad$ Regression Set 5 narrowed Set 4 by splitting up each of the Set 4 combinations by a fourth variable, S_ABILITY (i.e., Excellent, Good, Average, and Probation student ability). This set controlled for all four variables by including a simple regression for each combination.

\section{RESULTS}

After organizing the database of grades and executing the five regression sets just described, the following results were obtained.

\section{Regression Set 1: The Basic Model: GRADE and SIZE}

Regression Set 1 consisted of a single regression of GRADE on the dummy variable, C_SIZE. For this analysis, the 113,468 grade records in the database that pertained to upper-division business core courses were used. The result is shown in Table 4.

Table 4

Results of Regression Set 1

Effect of C_SIZE on GRADE: All 10 Business Core Classes, No Control Variables

\begin{tabular}{|c|c|c|c|c|c|}
\hline \multirow{2}{*}{$\begin{array}{c}\text { Adjusted } \\
\text { R-Square }\end{array}$} & $\begin{array}{c}\text { Significance } \\
\text { Level }\end{array}$ & Coefficient & \multicolumn{3}{|c|}{ Average Grades * } \\
\cline { 4 - 6 } & $\begin{array}{c}\text { Large } \\
\text { Classes }\end{array}$ & $\begin{array}{c}\text { Small } \\
\text { Classes }\end{array}$ & Difference \\
\hline .000 & .000 & .061 & $2.30[22348]$ & $2.24[91120]$ & .06 \\
\hline
\end{tabular}

* Grades are assigned on a scale from 0 to 4 . The number of grades used to compute each average is shown in brackets. 
This result can be interpreted as indicating that the students who were in large lecture-hall classes received course grades that were about .06 grade points higher (see the Difference column) than those who were in the smaller classes. The results are highly significant (with a Significance Level of .000), but not necessarily very meaningful (since the Adjusted R-Square rounds to .000). Since this study focuses on the use of control variables to isolate the effect of C_SIZE on GRADE, the results of each of the other four regression sets will be compared to this single result.

\section{Regression Set 2: Addition Of COURSE}

Regression Set 2 consisted of 10 regressions of GRADE on C_SIZE, one for each of the 10 upper-division business core courses that were offered in both small and large formats during the periods covered by the database:

(1) Managerial Accounting (ACCT-MGRL),

(2) Business Law II (BUS LAW),

(3) Money, Income, and International Economics (ECON-MIIE),

(4) Economic Price Theory (ECON-PT),

(5) Financial Management (FIN MGMT),

(6) Information Systems (INFO SYS),

(7) Management and Organizational Behavior (MGMT-OB),

(8) Marketing Management (MARKETING),

(9) Decision Support Models \& Methods (MSCI-DSS), and

(10) Operations Management (MSCI-OM).

The number of grades included in this analysis was 113,468 . The results are shown in Table 5.

Table 5

Results of Regression Set 2

Effect of C_SIZE on GRADE: COURSE as a Control Variable

\begin{tabular}{|c|c|c|c|c|c|c|}
\hline Control Variable & \multirow{2}{*}{$\begin{array}{c}\text { Adjusted } \\
\text { CoURSE }\end{array}$} & \multirow{2}{*}{$\begin{array}{c}\text { Significance } \\
\text { Level }\end{array}$} & \multirow{2}{*}{ Coefficient } & \multicolumn{3}{|c|}{ Average Grades * } \\
\cline { 5 - 7 } & & & $\begin{array}{c}\text { Large } \\
\text { Classes }\end{array}$ & $\begin{array}{c}\text { Small } \\
\text { Classes }\end{array}$ & Difference \\
\hline ACCT-MGRL & .002 & .000 & .385 & $2.80[100]$ & $2.41[5098]$ & .39 \\
\hline BUS LAW & .008 & .000 & .633 & $2.92[311]$ & $2.29[16017]$ & .63 \\
\hline ECON-MIIE & .003 & .000 & .398 & $2.15[329]$ & $1.75[8911]$ & .40 \\
\hline ECON-PT & .001 & .000 & .234 & $1.99[400]$ & $1.76[16395]$ & .23 \\
\hline FIN MGMT & .006 & .000 & $.201)$ & $2.20[3802]$ & $2.40[10531]$ & $(.20)$ \\
\hline INFO SYS & .002 & .000 & $.158)$ & $2.32[817]$ & $2.48[8504]$ & $(.16)$ \\
\hline MGMT-OB & .012 & .000 & $.223)$ & $2.31[8480]$ & $2.54[7038]$ & $(.23)$ \\
\hline MARKETING & .012 & .000 & $(.220)$ & $2.32[6985]$ & $2.54[7608]$ & $(.22)$ \\
\hline MSCI-DSS & .001 & .003 & $(.104)$ & $2.34[1003]$ & $2.44[8933]$ & $(.10)$ \\
\hline MSCI-OM & .006 & .000 & $(.336)$ & $2.14[121]$ & $2.48[2085]$ & $(.34)$ \\
\hline
\end{tabular}

* Grades are assigned on a scale from 0 to 4 . The number of grades used to compute each average is shown in brackets.

These results are different in both direction (positive/negative) and magnitude (measured in grade points) than the single positive .06 result arising from running Regression Set 1 (Table 4). In that result, it appeared that students taking large classes would do better, albeit slightly, than students taking smaller classes. In Regression Set 2 (Table 5), however, it appears that the effect of C_SIZE on GRADE is highly dependent upon which of the 10 business core courses was being taken. For $40 \%$ (4/10) of the courses, the effect was positive. For the other $60 \%$ $(6 / 10)$ of the courses, it was negative. 
It should also be noted that the Differences between the large and small classes are much more substantial when COURSE is used as a control variable than when it is not. When all 10 of the courses are examined together, the difference was .06. In contrast, when the analysis is done at the course level, the difference ranges from a low of negative .34 to a high of positive .63. Students in large sections of operations management (MSCI-OM) had grades that were .34 lower than did students in small sections while students in large sections of business law (BUS LAW) were shown to have grades that were .63 grade points higher than students in small sections.

Regression Set 3: Addition of C_LENGTH

Regression Set 3 consisted of 19 regressions of GRADE on C_SIZE, one for each of the 19 combinations of COURSE and C_LENGTH that were offered in both small and large formats. The number of grades included in this analysis was 55,802. The results are shown in Table 6.

The results for Regression Set 3 (Table 6) differ even more from the single result in Regression Set 1 than do the results just presented for Regression Set 2. For the 19 cases examined here, five showed a positive significant difference ("large classes are better"), eight showed a negative significant difference ("small classes are better"), and six showed no significant difference ("class size doesn't matter"). When compared to the single positive result in the first regression set, 14 of the 19 cases have been reclassified from a positive effect to either a negative effect or no effect.

Table 6

Results of Regression Set 3

Effect of C_SIZE on GRADE: COURSE and C_LENGTH as Control Variables

\begin{tabular}{|c|c|c|c|c|c|c|c|}
\hline \multicolumn{2}{|c|}{ Control Variables } & \multirow{2}{*}{$\begin{array}{l}\text { Adjusted } \\
\text { R-Square }\end{array}$} & \multirow{2}{*}{$\begin{array}{c}\text { Significance } \\
\text { Level }\end{array}$} & \multirow[b]{2}{*}{ Coefficient } & \multicolumn{3}{|c|}{ Average Grades ** } \\
\hline COURSE & C_LENGTH & & & & $\begin{array}{c}\text { Large } \\
\text { Classes }\end{array}$ & $\begin{array}{c}\text { Small } \\
\text { Classes }\end{array}$ & Difference \\
\hline ACCT-MGRL & 3 & .005 & .001 & .351 & $2.80[100]$ & $2.45[1712]$ & .35 \\
\hline BUS LAW & 3 & .021 & .000 & .578 & $2.92[311]$ & 2.34 [4220] & .58 \\
\hline ECON-MIIE & 3 & .013 & .000 & .445 & 2.15 [329] & $1.70[2275]$ & .45 \\
\hline \multirow[t]{2}{*}{ ECON-PT } & 1 & * & * & * & $2.02[80]$ & $1.79[6241]$ & .23 \\
\hline & 3 & .002 & .001 & .226 & 1.99 [320] & $1.76[3815]$ & .23 \\
\hline \multirow[t]{3}{*}{ FIN MGMT } & 1 & .012 & .000 & $(.282)$ & $2.09[2307]$ & $2.38[4240]$ & $(.29)$ \\
\hline & 1.5 & .002 & .006 & .128 & $2.55[628]$ & $2.42[3521]$ & .13 \\
\hline & 3 & .004 & .000 & $(.185)$ & $2.24[866]$ & $2.43[2725]$ & $(.19)$ \\
\hline \multirow[t]{2}{*}{ INFO SYS } & 1.5 & * & * & * & $2.37[439]$ & $2.37[4396]$ & .00 \\
\hline & 3 & * & * & * & $2.63[261]$ & 2.53 [3337] & .10 \\
\hline \multirow[t]{3}{*}{ MGMT-OB } & 1 & * & * & * & 2.60 [297] & 2.55 [2393] & .05 \\
\hline & 1.5 & .007 & .000 & $(.209)$ & $2.29[5611]$ & $2.50[1781]$ & $(.21)$ \\
\hline & 3 & .010 & .000 & $(.209)$ & 2.34 [2572] & $2.55[2864]$ & $(.21)$ \\
\hline \multirow[t]{3}{*}{ MARKETING } & 1 & .009 & .000 & $(.194)$ & 2.34 [1798] & $2.53[3094]$ & $(.19)$ \\
\hline & 1.5 & .009 & .000 & $(.191)$ & 2.32 [3188] & 2.51 [2448] & $(.19)$ \\
\hline & 3 & .017 & .000 & $(.276)$ & 2.32 [1999] & 2.59 [2036] & $(.27)$ \\
\hline \multirow[t]{2}{*}{ MSCI-DSS } & 2 & * & * & * & 2.29 [758] & 2.33 [1906] & $(.04)$ \\
\hline & 4 & * & * & * & $2.50[245]$ & $2.45[1427]$ & .05 \\
\hline MSCI-OM & 1.5 & .013 & .000 & $(.352)$ & $2.14[121]$ & 2.49 [921] & $(.35)$ \\
\hline
\end{tabular}

* Not significant at the $\alpha=.05$ level.

** Grades are assigned on a scale from 0 to 4 . The number of grades used to compute each average is shown in brackets. 


\section{Regression Set 4: Addition Of Instructor}

Regression Set 4 consisted of 50 regressions of GRADE on C_SIZE, one for each of the 50 combinations of COURSE, C_LENGTH, and INSTRUCTOR that were offered in both small and large formats. ${ }^{4}$ The number of grades included in this analysis was 14,162. The results are shown in Table 7.

When examining the results of Regression Set 4 (Table 7), the reader should note that: [1] although there are proportionately fewer statistically significant Differences here than in the results for earlier regression sets, the differences are substantially larger (a range from -1.36 to .78), [2] the sizes of the Adjusted R-Squares have improved, and [3] most of the Significance Levels are still very small.

These results also follow the trend over the last two regression sets of a steady increase in the proportion of cases (90\% or 45/50 either negative or no effect) that are inconsistent with Regression Set 1's finding of a small, but positive, relationship between class size and student performance.

Regression Set 5: Addition of S_ABILITY

Regression Set 5 consisted of 82 regressions of GRADE on C_SIZE, one for each of the 82 combinations of COURSE, C_LENGTH, INSTRUCTOR, and S_ABILITY that were offered in both small and large formats. ${ }^{5}$ The number of grades included in this analysis was 3,344. The results are shown in Table 8.

The results in Regression Set 5 (Table 8) are even stronger than those shown for Regression Set 4: Both the Differences and Adjusted R-Squares are quite a bit larger than before. When compared to Regression Set 1, the proportion of inconsistent cases is now $78 / 82$ or $95 \%$.

\section{SUMMARY \& CONCLUSIONS}

Although the effects of class size on student performance have been studied repeatedly, the results have been notably inconsistent. Of the 13 studies reviewed for this paper, three found negative effects, one found a positive effect, four found differential effects, and three found no effects. A possible reason for such inconsistent findings could be a shortage of control variables in previous studies.

The purpose of the current study was to test for the relationship between class size and student performance in the light of each of four control variables: the course being taught, the length of the class period, the instructor, and individual student ability. The approach used was to conduct a series of five regression sets. The first set was a simple regression of class size on student performance (similar to the approach taken in previous studies). The second and subsequent sets each consisted of a series of simple regressions that controlled first for one, then two, then three, and then finally four control variables.

The results of the five regression sets described earlier are presented in Table 9. A review of the various columns of the table reveal distinct patterns as each new control variable is added in progression. follows:

The pattern of results (in each of the six columns on the right-hand side of the table) is described as

- $\quad$ Adjusted R-Squares: The values have increased steadily from Regression Set 1 to Regression Set 5.

- $\quad$ Significance Levels: With few exceptions, all of the Regression Sets produced results that were highly significant.

- $\quad$ Signs of the Coefficient: Of all the 72 significant regressions in all five regression sets, 53 were negative and 19 were positive.

\footnotetext{
${ }^{4}$ There were actually 52 such combinations, but two were removed from consideration due to the low sample size for the small class size group ( $<15$ students).

${ }^{5}$ There were actually 198 such combinations, but in this case, 116 of the combinations were unusable due to a low sample size for at least one of the two class size groups when categorized by student ability level ( $n<15$ students).
} 
- $\quad$ Number of Grades: Although the sample size decreased from one regression set to the next, the sample size of the final regression set $(n=3,344)$ is still quite large.

- $\quad$ Percent of Significant Regressions: Even though these percentages of significant regressions out of the total regressions conducted are declining from one regression set to the next, the percentages are all substantially higher than would be expected to occur by chance. ${ }^{6}$

- Average Difference between Mean Grades: As more control variables are added into the regression sets, the difference between mean large and mean small class grades has steadily increased (i.e. from .06 through -.42).

After reviewing the pattern of these results, a number of conclusions can be reached:

- $\quad$ The results of the five regression sets showed a quite consistent and progressively stronger effect of class size as each of the four control variables were added. These findings lend credence to the investigators' initial belief that control variables can play an important role in testing for the effect of class size on student performance and suggest that future studies in this area should include such control variables in their design.

- If large classes do indeed have an effect (which they did in 21 of the 25 situations tested in the final regression set), then that effect appears to be negative.

- It may be that some instructors have much more difficulty with large sections than do others, as evidenced by the concentration of negative effects on particular instructors (See the MARKETING and MGMT-OB section of Table 8).

- $\quad$ The effect of large classes appears to be highly dependent upon the particular combination of course subject, class period length, instructor, and the ability of the students involved.

- It appears that large classes do not always have an effect on student performance. In 69\% (57/82) of the situations in the last regression set, no effect was found.

- The fact that $69 \%$ of the situations tested in the final regression set revealed no effect is difficult to interpret. It could be that there really is no effect or that additional control variables are needed to isolate the effect, if any.

\section{SUGGESTIONS FOR FUTURE RESEARCH}

Given these findings, future research could take a variety of paths, including: (a) an examination of class size for other courses, (b) the use of student demographic variables (e.g., gender, ethnicity, marital status, and age), (c) the introduction of other course configuration variables (e.g., daytime vs. nighttime, weekday vs. weekend), and/or (d) an investigation of the effects of various motivational variables (e.g., whether or not the course is in the student's major).

\footnotetext{
${ }^{6}$ At a significance level of $\alpha=.05$, one would expect $5 \%$ of a set of regressions to be significant just by chance. Percentages of significant regressions higher than this expected percentage are generally considered to be unlikely to occur in the absence of an underlying relationship between the independent and dependent variables.
} 
Table 7

Results of Regression Set 4

Effect of C_SIZE on GRADE: COURSE, C_LENGTH, and INSTRUCTOR as Control Variables

\begin{tabular}{|c|c|c|c|c|c|c|c|c|}
\hline \multicolumn{3}{|c|}{ Control Variables } & \multirow{2}{*}{$\begin{array}{c}\text { Adjusted } \\
\text { R-Squared }\end{array}$} & \multirow{2}{*}{$\begin{array}{c}\text { Significance } \\
\text { Level }\end{array}$} & \multirow[b]{2}{*}{ Coefficient } & \multicolumn{3}{|c|}{ Average Grades *夫 } \\
\hline COURSE & C_LENGTH & INSTRUCTOR & & & & $\begin{array}{l}\text { Large } \\
\text { Classes }\end{array}$ & $\begin{array}{c}\text { Small } \\
\text { Classes }\end{array}$ & Difference \\
\hline ACCT-MGRL & 3 & 268 & * & * & * & $2.80[100]$ & $2.82[168]$ & $(.02)$ \\
\hline BUS LAW & 3 & 466 & .062 & .000 & .572 & $2.64[218]$ & 2.07 [68] & .57 \\
\hline ECON-MIIE & 3 & 457 & .070 & .000 & .704 & 2.15 [329] & $1.44[163]$ & .71 \\
\hline ECON-PT & 1 & 392 & * & * & * & $2.02[80]$ & $2.08[539]$ & $(.06)$ \\
\hline \multirow{12}{*}{ FIN MGMT } & \multirow[t]{4}{*}{1} & 432 & * & * & * & $2.80[153]$ & 3.13 [39] & $(.33)$ \\
\hline & & 238 & .002 & .035 & (.205) & $2.04[153]$ & $2.25[180]$ & $(.20)$ \\
\hline & & 539 & * & * & * & $1.93[142]$ & $2.23[26]$ & $(.30)$ \\
\hline & & 287 & * & * & * & 2.12 [262] & $2.28[374]$ & $(.16)$ \\
\hline & 1.5 & 303 & .014 & .000 & .238 & $2.74[360]$ & 2.51 [1040] & .23 \\
\hline & \multirow[t]{7}{*}{3} & 218 & * & * & * & 2.88 [273] & $3.03[137]$ & $(.15)$ \\
\hline & & 238 & * & * & * & 2.13 [91] & $2.10[106]$ & .03 \\
\hline & & 287 & .049 & .001 & $(.548)$ & 1.86 [83] & $2.41[108]$ & $(.55)$ \\
\hline & & 551 & * & * & * & $1.85[122]$ & 1.97 [29] & (.12) \\
\hline & & 216 & * & * & * & $2.03[112]$ & $2.26[36]$ & (.23) \\
\hline & & 327 & * & * & * & $2.48[112]$ & $2.47[398]$ & .01 \\
\hline & & 378 & .196 & .000 & (1.358) & 1.05 [73] & $2.41[246]$ & $(1.36)$ \\
\hline \multirow[t]{3}{*}{ INFO SYS } & 1.5 & 438 & * & * & * & 2.36 [439] & 2.36 [62] & .00 \\
\hline & \multirow[t]{2}{*}{3} & 316 & .133 & .000 & .777 & $2.91[115]$ & $2.13[103]$ & .78 \\
\hline & & 136 & * & * & * & $2.40[146]$ & $2.52[220]$ & $(.12)$ \\
\hline \multirow[t]{12}{*}{ MGMT-OB } & \multirow[t]{2}{*}{1} & 310 & .044 & .001 & $(.308)$ & 2.74 [149] & 3.04 [81] & $(.30)$ \\
\hline & & 485 & * & * & * & $2.46[148]$ & $2.58[305]$ & (.12) \\
\hline & \multirow[t]{4}{*}{1.5} & 416 & .016 & .000 & $(.540)$ & 2.26 [2074] & $2.80[139]$ & $(.54)$ \\
\hline & & 385 & * & * & * & 2.36 [1033] & $2.41[568]$ & $(.05)$ \\
\hline & & 282 & .029 & .000 & $(.345)$ & $2.09[408]$ & $2.44[336]$ & $(.35)$ \\
\hline & & 456 & .038 & .000 & $(.568)$ & 2.33 [1033] & $2.90[181]$ & (.57) \\
\hline & \multirow[t]{6}{*}{3} & 416 & .064 & .000 & $(.576)$ & 1.95 [142] & $2.53[100]$ & $(.58)$ \\
\hline & & 385 & .009 & .005 & $(.249)$ & 2.15 [580] & 2.39 [209] & $(.24)$ \\
\hline & & 310 & .071 & .000 & $(.434)$ & 2.59 [288] & $3.03[148]$ & $(.44)$ \\
\hline & & 282 & * & * & * & $2.05[373]$ & $2.17[172]$ & (.12) \\
\hline & & 456 & * & * & * & $2.50[490]$ & 2.58 [138] & $(.08)$ \\
\hline & & 525 & * & * & * & $2.51[406]$ & $2.65[479]$ & (.14) \\
\hline \multirow[t]{14}{*}{ MARKETING } & \multirow[t]{5}{*}{1} & 184 & .017 & .003 & (.299) & 1.88 [91] & 2.18 [358] & $(.30)$ \\
\hline & & 427 & * & * & * & 2.46 [155] & $2.42[371]$ & .04 \\
\hline & & 187 & .007 & .025 & $(.185)$ & 2.64 [298] & $2.83[276]$ & (.19) \\
\hline & & 133 & * & * & * & 1.99 [81] & $1.90[34]$ & .09 \\
\hline & & 148 & .178 & .000 & $(.966)$ & $2.00[221]$ & $2.97[291]$ & $(.97)$ \\
\hline & \multirow[t]{5}{*}{1.5} & 242 & * & * & * & 2.47 [225] & 2.60 [78] & $(.13)$ \\
\hline & & 427 & .014 & .001 & $(.227)$ & $2.20[408]$ & $2.43[257]$ & (.23) \\
\hline & & 187 & .155 & .000 & $(1.034)$ & 2.19 [535] & $3.23[130]$ & $(1.04)$ \\
\hline & & 285 & * & * & * & $2.57[224]$ & $2.41[117]$ & .16 \\
\hline & & 204 & .004 & .017 & .163 & $2.26[591]$ & 2.38 [628] & $(.12)$ \\
\hline & \multirow[t]{4}{*}{3} & 242 & .219 & .000 & $(1.135)$ & $2.06[224]$ & 3.20 [69] & (1.14) \\
\hline & & 187 & .179 & .000 & $(.834)$ & $2.65[280]$ & 3.49 [248] & $(.84)$ \\
\hline & & 476 & * & * & * & $2.28[137]$ & 2.24 [62] & .04 \\
\hline & & 204 & * & * & * & $2.24[534]$ & 2.13 [67] & .11 \\
\hline \multirow[t]{4}{*}{ MSCI-DSS } & 2 & 262 & * & * & * & 2.39 [112] & $2.17[34]$ & .22 \\
\hline & & 174 & * & * & * & $2.24[404]$ & 2.28 [522] & $(.04)$ \\
\hline & 4 & 262 & .024 & .033 & .474 & $2.45[121]$ & 1.98 [29] & .47 \\
\hline & & 272 & * & * & * & $2.54[124]$ & $2.43[70]$ & .11 \\
\hline MSCl-OM & 1.5 & 333 & * & * & * & $2.14[121]$ & $2.39[131]$ & $(.25)$ \\
\hline
\end{tabular}

* Not significant at the $\alpha=.05$ level.

** Grades are assigned on a scale from 0 to 4 . The number of grades used to compute each average is shown in brackets. 
Table 8

Results of Regression Set 5

Effect of C_SIZE on GRADE: COURSE, C_LENGTH, INSTRUCTOR, and S_ABILITY as Control Variables

\begin{tabular}{|c|c|c|c|c|c|c|c|c|c|}
\hline \multicolumn{4}{|c|}{ Control Variables } & \multirow{2}{*}{$\begin{array}{l}\text { Adjusted } \\
\text { R-Square }\end{array}$} & \multirow{2}{*}{$\begin{array}{c}\text { Significance } \\
\text { Level }\end{array}$} & \multirow[b]{2}{*}{ Coefficient } & \multicolumn{3}{|c|}{ Average GRADE ** } \\
\hline COURSE & C_LENGTH & INSTRUCTOR & S_ABILITY & & & & $\begin{array}{c}\text { Large } \\
\text { Classes }\end{array}$ & $\begin{array}{c}\text { Small } \\
\text { Classes }\end{array}$ & Difference \\
\hline ACCT-MGRL & 3 & 268 & Average & * & * & * & $2.68[19]$ & $2.67[43]$ & .01 \\
\hline \multirow[t]{2}{*}{ ECON-MIIE } & \multirow[t]{2}{*}{3} & \multirow[t]{2}{*}{457} & Good & * & * & * & $2.60[43]$ & $2.17[24]$ & .43 \\
\hline & & & Average & * & * & * & $1.62[63]$ & $1.55[42]$ & .07 \\
\hline \multirow[t]{2}{*}{ ECON-PT } & \multirow[t]{2}{*}{1} & \multirow[t]{2}{*}{392} & Good & .056 & .008 & $(.595)$ & $2.14[20]$ & $2.73[87]$ & $(.59)$ \\
\hline & & & Average & * & * & * & $1.63[24]$ & $1.94[113]$ & $(.31)$ \\
\hline \multirow[t]{15}{*}{ FIN MGMT } & \multirow[t]{6}{*}{1} & \multirow[t]{3}{*}{238} & Excellent & * & * & * & 3.54 [116] & 3.48 [23] & .06 \\
\hline & & & Good & * & * & * & $2.81[190]$ & $2.64[36]$ & .17 \\
\hline & & & Average & * & * & * & $2.08[430]$ & $1.82[56]$ & .26 \\
\hline & & \multirow[t]{3}{*}{287} & Excellent & * & * & * & 3.38 [21] & $3.33[46]$ & .05 \\
\hline & & & Good & * & * & * & $2.63[44]$ & $2.63[46]$ & .00 \\
\hline & & & Average & * & * & * & $1.94[60]$ & $2.14[105]$ & $(.20)$ \\
\hline & \multirow[t]{4}{*}{1.5} & \multirow[t]{4}{*}{303} & Excellent & * & * & * & 3.75 [21] & $3.40[88]$ & .35 \\
\hline & & & Good & .020 & .020 & .351 & 3.12 [41] & 2.77 [176] & .35 \\
\hline & & & Average & * & * & * & 2.56 [91] & 2.43 [268] & .13 \\
\hline & & & Probation & .033 & .033 & .218 & 2.33 [28] & $2.11[82]$ & .22 \\
\hline & \multirow[t]{5}{*}{3} & 238 & Average & * & * & * & 1.69 [26] & 1.88 [27] & $(.19)$ \\
\hline & & 287 & Average & * & * & * & 1.94 [20] & $2.20[24]$ & $(.26)$ \\
\hline & & 327 & Average & * & * & * & 2.38 [26] & $2.25[106]$ & .13 \\
\hline & & 218 & Good & * & * & * & 3.52 [25] & 3.37 [18] & .15 \\
\hline & & & Average & * & * & * & 2.79 [52] & 3.18 [33] & $(.39)$ \\
\hline INFO SYS & 3 & 316 & Average & .100 & .009 & .675 & 2.78 [18] & 2.10 [39] & .68 \\
\hline & & 136 & Good & * & * & * & 2.59 [26] & 2.87 [26] & $(.28)$ \\
\hline & & & Average & .039 & .029 & $(.333)$ & 2.23 [40] & $2.56[56]$ & $(.33)$ \\
\hline & & & Probation & * & * & * & 2.20 [15] & 2.27 [20] & $(.07)$ \\
\hline MGMT-OB & 1 & 310 & Good & * & * & * & 3.04 [17] & 3.38 [18] & $(.34)$ \\
\hline & & & Average & .046 & .044 & $(.248)$ & 2.72 [35] & 2.97 [32] & $(.25)$ \\
\hline & & 485 & Excellent & * & * & * & 3.65 [15] & $3.30[40]$ & .35 \\
\hline & & & Average & .030 & .043 & .327 & 2.43 [45] & $2.11[59]$ & .32 \\
\hline & 1.5 & 416 & Good & .013 & .028 & $(.395)$ & 2.72 [280] & 3.12 [23] & $(.40)$ \\
\hline & & & Average & .025 & .000 & $(.507)$ & 2.23 [507] & $2.74[42]$ & $(.51)$ \\
\hline & & 385 & Excellent & * & * & * & 3.48 [82] & $3.45[56]$ & .03 \\
\hline & & & Good & * & * & * & $2.98[118]$ & 3.14 [81] & $(.16)$ \\
\hline & & & Average & * & * & * & 2.42 [251] & 2.37 [151] & .05 \\
\hline & & & Probation & * & * & * & $2.04[70]$ & 1.89 [32] & .15 \\
\hline & & 282 & Excellent & * & * & * & 3.25 [32] & 2.93 [33] & .32 \\
\hline & & & Good & * & * & * & 2.53 [62] & 2.79 [48] & $(.26)$ \\
\hline & & & Average & .046 & .002 & $(.386)$ & 2.10 [111] & 2.49 [83] & $(.39)$ \\
\hline & & 456 & Excellent & * & * & * & 3.44 [73] & 3.44 [25] & .00 \\
\hline & & & Good & .026 & .019 & $(.343)$ & 2.89 [145] & 3.23 [32] & $(.34)$ \\
\hline & & & Average & .054 & .000 & $(.607)$ & 2.40 [253] & $3.02[34]$ & $(.62)$ \\
\hline & 3 & 416 & Good & * & * & * & 2.65 [22] & 3.04 [19] & $(.39)$ \\
\hline & & & Average & .292 & .000 & $(.905)$ & 1.71 [32] & 2.62 [17] & $(.91)$ \\
\hline & & 385 & Good & * & * & * & $2.77[70]$ & 2.85 [23] & $(.08)$ \\
\hline & & & Average & * & * & * & 2.17 [111] & $2.13[50]$ & .04 \\
\hline & & 310 & Good & * & * & * & 2.95 [28] & 3.12 [28] & $(.17)$ \\
\hline & & & Average & .103 & .002 & (.389) & 2.66 [54] & 3.05 [29] & (.39) \\
\hline & & 282 & Excellent & * & * & * & 3.26 [25] & 3.09 [22] & .17 \\
\hline & & & Good & * & * & * & $2.55[40]$ & 2.60 [18] & $(.05)$ \\
\hline & & & Average & * & * & * & 2.10 [92] & $2.10[26]$ & .00 \\
\hline & & 456 & Good & * & * & * & $2.70[71]$ & $2.99[24]$ & $(.29)$ \\
\hline & & & Average & .026 & .033 & $(.307)$ & 2.36 [99] & 2.66 [38] & $(.30)$ \\
\hline
\end{tabular}


Table 8 (continued)

\section{Results of Regression Set 5}

\begin{tabular}{|c|c|c|c|c|c|c|c|c|c|}
\hline \multicolumn{4}{|c|}{ Control Variables } & \multirow{2}{*}{$\begin{array}{l}\text { Adjusted } \\
\text { R-Square }\end{array}$} & \multirow{2}{*}{$\begin{array}{c}\text { Significance } \\
\text { Level }\end{array}$} & \multirow[b]{2}{*}{ Coefficient } & \multicolumn{3}{|c|}{ Average GRADE ** } \\
\hline COURSE & C_LENGTH & INSTRUCTOR & S_ABILITY & & & & $\begin{array}{c}\text { Large } \\
\text { Classes }\end{array}$ & $\begin{array}{c}\text { Small } \\
\text { Classes }\end{array}$ & Difference \\
\hline \multirow[t]{25}{*}{ MARKETING } & \multirow[t]{8}{*}{1} & 184 & Average & * & * & * & 1.93 [25] & $2.09[100]$ & $(.16)$ \\
\hline & & 427 & Average & * & * & * & $2.47[24]$ & $2.42[102]$ & .05 \\
\hline & & \multirow[t]{3}{*}{187} & Excellent & * & * & * & 3.47 [27] & $3.68[28]$ & $(.21)$ \\
\hline & & & Good & * & * & * & $3.14[46]$ & $3.25[48]$ & $(.11)$ \\
\hline & & & Average & * & * & * & $2.75[88]$ & $2.96[63]$ & $(.21)$ \\
\hline & & \multirow[t]{3}{*}{148} & Excellent & .258 & .000 & $(1.142)$ & $2.77[21]$ & $3.91[22]$ & $(1.14)$ \\
\hline & & & Good & .387 & .000 & $(1.029)$ & $2.65[20]$ & $3.67[43]$ & $(1.02)$ \\
\hline & & & Average & .208 & .000 & (.909) & $2.15[48]$ & $3.06[66]$ & $(.91)$ \\
\hline & \multirow[t]{12}{*}{1.5} & 242 & Average & * & * & * & $2.72[59]$ & $2.57[21]$ & .15 \\
\hline & & \multirow[t]{4}{*}{427} & Excellent & * & * & * & 3.19 [32] & $3.21[22]$ & $(.02)$ \\
\hline & & & Good & * & * & * & $2.70[52]$ & $2.91[48]$ & $(.21)$ \\
\hline & & & Average & * & * & * & 2.29 [99] & $2.38[77]$ & $(.09)$ \\
\hline & & & Probation & .090 & .029 & (.499) & $1.81[20]$ & $2.30[23]$ & (.49) \\
\hline & & \multirow[t]{2}{*}{187} & Excellent & .174 & .001 & $(.452)$ & $3.42[43]$ & $3.88[16]$ & $(.46)$ \\
\hline & & & Average & .309 & .000 & (1.243) & 2.03 [122] & 3.27 [37] & $(1.24)$ \\
\hline & & 285 & Average & * & * & * & $2.58[40]$ & $2.41[32]$ & .17 \\
\hline & & \multirow[t]{4}{*}{204} & Excellent & * & * & * & $3.23[46]$ & $3.33[53]$ & $(.10)$ \\
\hline & & & Good & * & * & * & 2.88 [73] & 2.78 [93] & .10 \\
\hline & & & Average & * & * & * & 2.32 [128] & 2.35 [149] & (.03) \\
\hline & & & Probation & * & * & * & 1.88 [38] & $2.10[41]$ & (.22) \\
\hline & \multirow[t]{5}{*}{3} & \multirow[t]{2}{*}{242} & Good & .338 & .000 & $(.807)$ & 2.47 [29] & 3.27 [22] & $(.80)$ \\
\hline & & & Average & .361 & .000 & (1.155) & 1.99 [57] & 3.14 [22] & (1.15) \\
\hline & & \multirow[t]{2}{*}{187} & Good & .132 & .001 & $(.408)$ & 3.33 [35] & 3.74 [33] & $(.41)$ \\
\hline & & & Average & .428 & .000 & (1.222) & $2.43[62]$ & $3.65[66]$ & (1.22) \\
\hline & & 204 & Average & * & * & * & 2.31 [145] & 2.18 [19] & .13 \\
\hline \multirow[t]{5}{*}{ MSCI-DSS } & \multirow[t]{4}{*}{2} & \multirow[t]{4}{*}{174} & Excellent & * & * & * & $3.22[49]$ & 3.29 [45] & $(.07)$ \\
\hline & & & Good & * & * & * & $2.69[55]$ & $2.79[111]$ & $(.10)$ \\
\hline & & & Average & * & * & * & 2.14 [128] & $2.16[166]$ & $(.02)$ \\
\hline & & & Probation & * & * & * & 1.59 [31] & 1.72 [33] & (.13) \\
\hline & 4 & 272 & Average & * & * & * & 2.59 [34] & $2.23[21]$ & .36 \\
\hline MSCI-OM & 1.5 & 333 & Average & * & * & * & $2.21[41]$ & $2.46[37]$ & $(.25)$ \\
\hline
\end{tabular}

* Not significant at the $\alpha=.05$ level.

** Grades are assigned on a scale from 0 to 4 . The number of grades used to compute each average is shown in brackets.

\section{REFERENCES}

1. Berghel, H. (1986). "Computer literacy programs: The effects of the large-class setting on student performance." College Microcomputer, 4, 69-81.

2. Borden, V. M., (1999). "The Impact of Class Size on Student Performance in Introductory Courses.” AIR Annual Forum Paper. Eric Document Reproduction Service No. ED433 782)

3. Eash, M. J., \& Bennett, C. M. (1964). American Educational Research Journal, 1, $229-239$.

4. Gibbs, G., \& Lucas, L. (1996). "Class size and student performance: 1984-94." Studies in Higher Education, 21 (3), 261-73.

5. Henebry, K. (1997). "The impact of class schedule on student performance in a financial management course." Journal of Education for Business, 73, 114-120.

6. Hou, J. W. (1994). Class size and determinants of learning effectiveness. Long Beach, California. (Eric Document Reproduction Service No. ED377 239)

7. Kennedy, P. E., \& Siegfried J. J. (1997). "Class size and achievement in introductory economics: Evidence from the TUCE III data." Economics of Education Review, 16 (4), October, 385-94.

8. Lindsay, R. O., \& Paton-Saltzberg, R. (1987). "Resource changes and academic performance at an English polytechnic." Studies in Higher Education, 12 (2), 213-227. 
9. Morgan, J. (1978). The effect of increasing class size on the grades of students in the business curriculum at Piedmont Technical College. Fort Lauderdale, Florida. (Eric Document Reproduction Service No. ED162 701)

10. Raimondo, H., Esposito, L., \& Gershenberg, I. (1990). "Introductory class size and student performance in intermediate theory courses." Journal of Economic Education, fall, 369-381.

11. Scheck, C., Kinicki, A., \& Webster, J. (1994). "The effect of class size on student performance: Development and assessment of a process model." Journal of Education for Business, 70, 104-111.

12. Sugrue, B., Rietz, T., \& Hansen, S. (1999). "Distance Learning: Relationships among Class Size, Instructor Location, Student Perceptions, and Performance.” Performance Improvement Quarterly, 12 (3), 44-57.

13. Thibodeaux, M. S., \& Zuzan, F.A. (1984). "The effects of class size on selected variables in a collegiate principles of management class: An exploratory study," Journal of Business Education, 59 (5), 178-182.

14. Williams, D., Cook, P., \& Jensen, R. (1984). Class size and achievement among college students. New Orleans, Louisiana. (Eric Document Reproduction Service No. ED245589).

Table 9

Summary of Regression Set Results

\begin{tabular}{|c|c|c|c|c|c|c|c|c|c|c|c|c|}
\hline \multirow[b]{2}{*}{$\begin{array}{l}\text { Regression } \\
\text { Set \# }\end{array}$} & \multirow{2}{*}{ 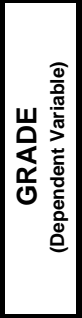 } & \multirow{2}{*}{ 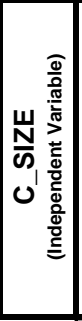 } & \multirow[b]{2}{*}{ 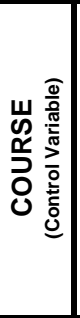 } & \multirow[b]{2}{*}{ 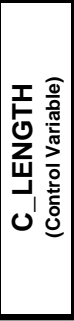 } & \multirow{2}{*}{ 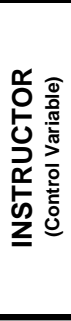 } & \multirow[b]{2}{*}{ 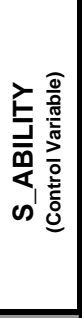 } & \multicolumn{5}{|c|}{ Summary of Regression Results } & \multirow{2}{*}{$\begin{array}{c}\text { Difference } \\
\text { between } \\
\text { Mean } \\
\text { Large and } \\
\text { Mean } \\
\text { Small } \\
\text { Class } \\
\text { Grades } \\
\text { (Average) } \\
\end{array}$} \\
\hline & & & & & & & $\begin{array}{c}\text { Adjusted } \\
\text { R-Square } \\
\text { (Range) }\end{array}$ & $\begin{array}{l}\text { Significance } \\
\text { Level } \\
\text { (Range) }\end{array}$ & $\begin{array}{l}\text { Signs of the } \\
\text { Coefficient }\end{array}$ & $\begin{array}{c}\text { Number } \\
\text { of Grades }\end{array}$ & $\begin{array}{c}\text { Percent of } \\
\text { Significant } \\
\text { Regressions }\end{array}$ & \\
\hline 1 & \multicolumn{2}{|c|}{ All courses } & & & & & .000 & .000 & $\begin{array}{c}\text { Negative: } 0 \\
\text { Positive: } 1\end{array}$ & 113,468 & $\begin{array}{c}100 \% \\
(1 / 1)\end{array}$ & .06 \\
\hline 2 & \multicolumn{4}{|c|}{$\begin{array}{l}\text { Courses having } \\
\text { both large and } \\
\text { small sections. }\end{array}$} & & & $\begin{array}{l}.001 \\
\text { to } \\
.012\end{array}$ & $\begin{array}{l}.000 \\
\text { to } \\
.003\end{array}$ & $\begin{array}{l}\text { Negative: } 6 \\
\text { Positive: } 4\end{array}$ & 113,468 & $\begin{array}{c}100 \% \\
(10 / 10)\end{array}$ & .06 \\
\hline 3 & \multicolumn{5}{|c|}{$\begin{array}{l}\text { Courses having both } \\
\text { large and small } \\
\text { sections, grouped by } \\
\text { class period length. }\end{array}$} & & $\begin{array}{l}.002 \\
\text { to } \\
.021\end{array}$ & $\begin{array}{l}.000 \\
\text { to } \\
.006\end{array}$ & $\begin{array}{c}\text { Negative: } 8 \\
\text { Positive: } 5\end{array}$ & 55,802 & $\begin{array}{c}68 \% \\
(13 / 19)\end{array}$ & -.04 \\
\hline 4 & \multicolumn{6}{|c|}{$\begin{array}{l}\text { Courses having both large } \\
\text { and small sections, grouped } \\
\text { by class period length and } \\
\text { instructor. }\end{array}$} & $\begin{array}{l}.002 \\
\text { to } \\
.219\end{array}$ & $\begin{array}{l}.000 \\
\text { to } \\
.035\end{array}$ & $\begin{array}{c}\text { Negative: } 18 \\
\text { Positive: } 5\end{array}$ & 14,162 & $\begin{array}{c}46 \% \\
(23 / 50)\end{array}$ & -.26 \\
\hline 5 & \multicolumn{6}{|c|}{$\begin{array}{l}\text { Courses having both large and small } \\
\text { sections, grouped by class period } \\
\text { length, instructor, and student ability } \\
\text { level. }\end{array}$} & $\begin{array}{l}.013 \\
\text { to } \\
.428\end{array}$ & $\begin{array}{l}.000 \\
\text { to } \\
.044\end{array}$ & $\begin{array}{c}\text { Negative: } 21 \\
\text { Positive: } 4\end{array}$ & 3,344 & $\begin{array}{c}31 \% \\
(25 / 82)\end{array}$ & -.42 \\
\hline
\end{tabular}


Notes 